\title{
Peningkatan pengetahuan dan sikap dalam pencegahan perilaku seksual berisiko melalui intervensi brief terapi dan life skill (biskill) pada remaja
}

\section{Knowledge and attitude improvement in prevention of risk sexual behavior through brief therapy intervention and life skill (biskill) in adolescents}

\author{
Muhammad Bachtiar Safrudin ${ }^{1, *}$, Thomas Arie Wibowo ${ }^{2}$ \\ ${ }^{1,2}$ Universitas Muhammadiyah Kalimantan Timur, J1. Ir H. Juanda No. 12 Samarinda, Kalimantan Timur, Indonesia \\ ${ }^{1}$ mbs134@umkt.ac.id*, ${ }^{2}$ taw12@umkt.ac.id \\ ${ }^{*}$ Corresponding author
}

Tanggal Submisi: 26 Maret 2021, Tanggal penerimaan: 18 Mei 2021

\begin{abstract}
Abstrak
Masa remaja terjadinya banyak perubahan tahap tumbuh kembang berisiko yang dapat menyebabkan berbagai permasalahan. Penanganan masalah memalui program pemerintah belum memberikan dampak yang signifikan. Tujuan penelitian ini mengetahui efektifitas intervensi brief theraphy dan life skill (biskill) dengan tujuan meningkatnya pengetahuan dan sikap remaja dalam pencegahan perilaku seksual berisiko. Jenis penelitian ini merupakan quasi experiment dengan pendekatan pengukuran sebelum dan setelah menggunakan kontrol (without control group design). Populasi yang digunakan adalah remaja yang ada di SMPN 27 Samarinda dengan sampel penelitian sebesar 135 siswa intervensi. Hasil penelitian dilakukan dengan analisis univariat dan bivariat paired $t$ test. Hasil uji statistik biskill terhadap pengetahuan menjukkan $\mathrm{p}$ value 0,000 dan biskill terhadap sikap dengan nilai 0,000 . Dapat disimpulkan Ha diterima, dimana biskill mempengaruhi pengetahuan dan sikap remaja di SMPN 27 Samarinda.
\end{abstract}

Kata kunci: brief terapi, life skill, pengetahuan, sikap, perilaku berisiko

\begin{abstract}
In adolescence there are many changes in the risk of growth and development that can cause various problems. The handling of problems through government programs has not yet had a significant impact. The purpose of this research is to find out the effectiveness of brief theraphy and life skill (biskill) interventions in improving the knowledge and attitudes of adolescents in preventing risky sexual behavior. This type of research is a quasi experiment with a pre and post without control group design approach. The study population was adolescents in SMPN 27 Samarinda with a sample of 135 intervention students. Analysis of the study was carried out by univariate and bivariate paired t test analyzes. Biskill statistical test results on knowledge showed a $p$ value of 0,000 and biskill on attitudes with a value of 0,000. It can be concluded that Ha was accepted, where biskill influenced the knowledge and attitudes of adolescents at SMPN 27 Samarinda.
\end{abstract}

Keywords: brief therapy, life skills, knowledge, attitudes, risk behaviors 


\section{PENDAHULUAN}

Masa remaja terjadinya banyak perubahan sehingga membutuhkan perhatian khusus dalam menjaga kesehatan terutama kesehatan reproduksi. (Catio, 2009). Permasalahan remaja dilanjutkan kembali dalam tujuan baru Perserikatan Bangsa-Bangsa yakni Sustainable Development Goals (Arnett, 2014).

Menurut catatan WHO sekitar 1,2 milyar penduduk dunia adalah remaja dengan rentang usia 10 sampai 19 tahun. Hasil sensus penduduk tahun 2010 di Indonesia menunjukkan 1 dari 4 orang penduduk Indonesia merupakan kaum muda berusia 10- 24 tahun, dari 240 juta penduduk Indonesia, jumlah remaja terbilang besar, mencapai 63,4 juta atau sekitar $26,7 \%$ dari total penduduk. Dengan jumlah yang tidak sedikit, remaja Indonesia menghadapi berbagai persoalan dalam kehidupan dunia remaja. Data Negara Indonesia menjukkan seperlima penduduk usia remaja memiliki resiko terhadap tahapan tumbuh kembnag yang dilalui dalam jangka panjang tersebut. Perilaku berisiko yang terjadi pada reja akibat adopsi pergaulan tidak sehat dan dampak informasi tanpa pemataunan yang benar (Gavin et al., 2010).

Perilaku seksual remaja di Indonesia saat ini sudah sangat mengkhawatirkan, termasuk di Kalimantan Timur. Hal ini dapat dilihat dari data tentang perilaku seksual pranikah remaja di Kota Samarinda Propinsi Kalimantan Timur menunjukkan bahwa 56,9\% pernah kissing, 30,7 necking, $13,8 \%$ petting, $7,2 \%$ oral seks, 5,5\% anal seks dan $14,7 \%$ pernah melakukan intercourse (Purwanto \& Kalsum, 2018). Hasil penelitian Suwarni dan Selviana (2015) menunjukkan inisiasi seks remaja diawali dengan pegangan tangan $(82,7 \%)$, berpelukan $(60,7 \%)$, cium pipi $(66 \%)$, meraba daerah sensitive $(19,3 \%)$, seks oral (7\%), seks anal (4\%) dan intercourse $(14,7 \%)$ (Suwarni \& Selviana, 2015)

Kenyataannya permasalahan remaja masih sangat banyak dengan berbagai program yang sudah dilakukan. Salah satu program penenganan masalah remaja adalah PKPR. Data di Kabupaten Kota Samarinda, program PKPR baru mulai dilaksanakan pada tahun 2007. Akan tetapi tidak semua Puskesmas di Kota Samarinda melaksanakan program ini (Ayundari \& Rahman, 2017).

Keberhasilan program pemerintah ini belum terlalu terlihat secara signifikan. Hasil Riset Kesehatan Dasar (Riskesdas) 2013 yang menyatakan 46\% perempuan Indonesia menikah sebelum berusia 20 tahun (Riset Kesehatan Dasar, 2013). Pengkajian yang dilakukan di salah satu SMP Wilayah Kerja Puskesmas Sempaja menunjukkan sebanyak 85\% siswa berpacaran dari total 209 siswa. Pengkajian lanjut terkait aktivitas berpacaran sebanyak 65\% pernah perpegangan tangan, berciuman sebanyak $32,94 \%$, pernah berpelukan dengan tangan diluar baju sebanyak $31,74 \%$ dan berpelukan dengan tangan didalam baju sebanyak $2,3 \%$.

Intervesi motalitas yang dikembangkan dalam praktek keperawatan ini adalah brief therapy dengan memadukan program PKPR yakni life skill yang yang dimaksud keterampilan memecahkan masalah, keterampilan berfikir kritis, keterampilan mengambil keputusan, keterampilan berfikir kreatif, keterampilan komunikasi interpersonal, keterampilan mengatasi stress dan emosi (Esadia, 2019)

Biskill merupakan penggabungan life therapy dan Brief terapi yang merupakan pengembangan Multi Dimensiional Family Terapi (MDFT) atau multi dimensi terapi keluarga (MDTK) adalah sebuah pendekatan keluarga, untuk remaja yang berisiko. Pendekatan target area MDFT terdiri dari (1) Remaja (2) orangtua (3) interaksi (4) sistem sosial extra family (Belsky et al., 2014). 
Tujuan penelitian ini mengetahui efektifitas intervensi brief theraphy dan life skill (biskill) dengan tujuan meningkatnya pengetahuan dan sikap remaja dalam pencegahan perilaku seksual berisiko. Kntribusi dari penelitian ini memberikan intervensi brief theraphy dan life skill (biskill) dengan tujuan pengetahuan dan sikap remaja dalam pencegahan perilaku seksual berisiko dapat meningkat.

\section{METODE PENELITIAN}

Penilitian ini menggunakan desain quasi experiment melalaui pendekatan pre-post test without contro, dimana peneliti melakukan intervensi pada satu kelompok tanpa pembanding. Intervensi perlakuan dinilai dengan cara membandingkan nilai pengukuran sebelum dan setelah intervensi (Notoatmodjo, 2012)). Sampel dalam studi ini adalah kelompok remaja yang di SMPN 27 Samarinda, yang dihitung dengan menggunakan uji hipotesis 2 mean didapatkan jumlah sampel sebesar 135 orang remaja (Nursalam, 2016).

Penilaian pengetahuan dan sikap remaja menggunakan kuesioner dari Kemenkes 2016. Instrumen tingkat pengetahuan terdiri 23 item pertanyaan dengan alternative jawaban yang digunakan adalah benar atau salah. Instrumen ini telah teruji validitas dan reliabilitasnya. Nilai validitas kuesioner pengetahuan adalah $88,6 \%$ dan nilai reliabilitasnya adalah $72 \%$. Instrumen tingkat sikap terdiri dari 16 item pernyataan dengan pilihan jawaban selalu, sering, kadangkadang, jarang dan tidak pernah. Nilai validitas untuk kuesioner sikap adalah $87 \%$ dan nilai reliabilitasnya adalah $84 \%$.

Penilaian pengetahuan dan sikap remaja dilakukan menggunakan kuesioner tingkat pengetahuan dan sikap remaja dalam pencegahan perilaku seksual berisiko oleh kemenkes 2016. Instrumen tingkat pengetahuan terdiri dari 23 item pertanyaan dengan pilihan jawaban benar dan salah. Instrumen ini telah teruji validitas dan reliabilitasnya. Nilai validitas kuesioner pengetahuan adalah $88,6 \%$ dan nilai reliabilitasnya adalah $72 \%$. Instrumen tingkat kepatuhan terdiri dari 16 item pernyataan dengan pilihan jawaban selalu, sering, kadang-kadang, jarang dan tidak pernah. Nilai validitas untuk kuesioner kepatuhan adalah $87 \%$ dan nilai reliabilitasnya adalah $84 \%$. Alur penelitian ini digambarkan sebagai berikut :

Analisis univariat pada penelitian ini dilakukan untuk manganalisis secara deskriptif variabel penelitian. Data kategorik akan ditampilkan dalam bentuk distribusi frekuensi dan persentase. Data numerik yaitu tingkat pengetahuan ditampilkan dalam bentuk mean, SD, minmaks bila data berdistribusi normal atau dalam bentuk median, min-maks 95\% CI bila data tidak berdistribusi normal. Normalitas data ditentukan dengan melihat rasio skewness-SE. Analisis bivariat dilakukan untuk melihat efektifitas metode biskill terhadap tingkat pengetahuan dan sikap siswa dalam pencegahan perilaku seksual berisiko. Uji yang digunakan untuk melihat perbedaan hasil posttest antara kelompok intervensi yaitu paired t test dan analisis dilakukan menggunakan SPSS versi 21. Uji bivariat dianggap bermakna bila $\mathrm{p}<0,05$.

\section{HASIL DAN PEMBAHASAN}

\section{Pengetahuan dan Sikap}

Tabel 1. Analisis variabel pengetahuan sebelum dan seteleh diberikan Intervensi biskill pada pada Remaja

\begin{tabular}{lccll}
\hline Variabel & Mean & SD & Min-Maks & $95 \%$ CI \\
\hline Pre Intervensi & 12 & 2.23 & $6-20$ & $11.4-12.16$ \\
Post Intervensi & 19 & 2.18 & $12-23$ & $19.19-19.94$ \\
\hline
\end{tabular}


Tabel 1 menjelaskan nilai rerata skor pengetahuan 12 dengan nilai terendah 5 dan nilai tertinggi 20, sedangakan interval kepercayaan $95 \%$ untuk nilai terendah 11,4 dan nilai tertinggi 12,16. Pengukuran setelah dilakukan intervensi brief therapy dan life skill didapatkan rerata yaitu 19 dengan nilai terendah 12 dan nilai tertingg 23 sedangkan interval kepercayaan $95 \%$ untuk nilai terendah 19,19 dan nilai tertinggi 19,94.

Tabel 2. Analisis Variabel Sikap sebelum dan seteleh diberikan Intervensi biskill pada pada Remaja

\begin{tabular}{lccll}
\hline Variabel & Mean & SD & Min-Maks & $95 \%$ CI \\
\hline Pre Intervensi & 37 & 6.35 & $21-60$ & $35.19-37.27$ \\
Post Intervensi & 60 & 6.31 & $40-70$ & $58.89-61.04$ \\
\hline
\end{tabular}

Tabel 2 menerangkan bahwa nilai rerata skor pengetahuan 37 dengan nilai terendah 21 dan nilai tertinggi 60, sedangakan interval kepercayaan 95\% untuk nilai terendah 35,19 dan nilai tertinggi 37,27. Pengukuran setelah dilakukan intervensi brief therapy dan life skill didapatkan rerata yaitu 60 dengan nilai terendah 40 dan nilai tertingg 70 sedangkan interval kepercayaan $95 \%$ untuk nilai terendah 58,89 dan nilai tertinggi 61,04.

Hasil analisis uji statistik menunjukkan bahwa pada variabel pengetahuan diukur dengan nilai $p$ adalah 0.000 dari hasil tersebut dapat disimpulkan bahwa adanya pengaruh yang bermakna skor pengetahuan sebelum dan sesudah diberikan intervensi biskill ( $p$ value $<\alpha=$ 0.05). Sehingga dapat disimpulkan Ha diterima, artinya terdapat pengaruh biskill dengan peningkatan pengetahuan remaja.

Uji statistik variabel sikap diperoleh nilai $p$ 0.000, hasil tersebut menujukkan bahwa terdapat pengaruh yang bermakna skor sikap sebelum dan sesudah diberikan intervensi melalui biskill. nial $p<\alpha 0.05$, dengan angka tersebut menunjukkan hipotesis altenatif diterima. Artinya, ada pengaruh biskill dengan peningkatan sikap pada remaja.

\section{Analisis Pengaruh Biskill Terhadap Pengetahuan dan Sikap Remaja di SMPN 27 Wilayah kerja Puskesmas SempajaTahun 2018.}

Perilaku menyimpang akan mengakibatkan permasalahan pada remaja, salah satunya adalah masalah kesehatan reproduksi. Pemahaman melalui pendidikan kesehatan yang menekankan pada aspek keterampilan hidup yang disebut dengan life skill. Aspeknya mencakup domain: tahap pertumbuhan dan perkembangan, kesehatan reproduksi dan permasalahannya harus diberikan sejak dini. Melaui kegiatan Trias UKS dengan melibatkan KKR diharapkan masalah seperti ini dapat ditangani (Al Amin et al., 2019)

Mengacu pada Undang-Undang RI Tahun 2003 tetang pendidikan Nasional. Penjelasan UU tersebut menayatkan sumberdaya yang berkualias akan meningkatkan upaya tujuan pembangunan dibidang pendidikan. Upaya pembetukan SDM ini dengan menciptakan lingkungan pendidikan sehat bagi peserta didik (Catio, 2009). Tujuan akhir yang ingin dicapai adalah peningkatan derajat kesehatan siswa, melalui pendidikan kesehatan reproduksi untuk remaja di sekolah. Pendidikan kesehatan diselenggarakan dengan tujuan untuk mengambangkan potensi siswa, memiliki akhlak yang mulia, memiliki kecapakan, sehat secara fisik dan psikis, berilmu, memiliki kreatifitas yang tinggi, mandiri serta membentuk jati diri sebagai warga neraga yang baik dan bertanggung jawab (Undang-Undang, 2003)

Gambaran pengetahuan remaja di SMP 27 Samarinda menjukkan rerata skor 12 sebelum dengan nilai min-mak (6-20). Sedangkan sikap menujukkan skor rerata 36 dengan nilai min-mak (21-60). Dari hasil ini menjukkan level pengetahuan dan sikap remaja cukup 
rendah. Jika dilihat dari hasil wawancara 10 remaja menujukkan jarangnya edukasi tetang kesehatan reproduksi dari guru atau petugas kesehatan.

Hasil penelitian ini berbeda dengan penelitian menjukkan tingkat pengetahuan siswa kelas XII SMA Negeri 1 Medan tentang kesehatan reproduksi remaja sebagian besar baik (95.6 $\%)$. Peningkatan pengetahuan dan sikap dikarenakan responden telah menerima pendidikan tentang sistem reproduksi yang terdapat dalam kurikulum pelajaran biologi sejak di bangku SMP yang mencakup topik kesehatan reproduksi (Desyolmita \& Firman, 2013).

Masalah kesehatan remaja merupakan salah satu risiko berkaitan dengan kesehatan reproduksi yang disebabkan rendahnya pengetahuan. Pentingnya peningkatan pemahaman melalui penerapan kurikulum kesehatan reproduksi. Beberapa materi seharusnya sudah diberikan dalam mata pelajaran Biologi (Hidayatun Najah, 2010). Penerapan kurikulum kesehatan reproduksi mengacu pada kurikulum muatan lokal sekolah yang diberikan baik dalam pelajaran BK atau pelajaran olahraga. Pelaksanaan muatan local terkait dengan kesehatan reproduksi sudah dilakukan di SMPN 27 Samarinda, akan tetapi belum berjalan dengan baik karena tidak adanya modul atau panduan baku yang dapat diterapkan secara terstruktur. Aplikasi atau pelaksanaan muatan lokal ini hanya sebatas pemberian edukasi kesehatan yang diberikan oleh guru bimbingan konseling (BK) saat jam pelajaran BK.

Penelitian menujukkan pelaksanaan pendidikan kesehatan reproduksi dan Napza melalui kelompok swabantu efektif dalam menekan perilaku berisiko pada remaja di SMA/SMK (Nurhayati, 2013). Sejalan dengan hasil penelitian ini yang membuktikan bahwa terdapat hubungan yang Signifikan antara pengetahuan tinggi, sikap positif dan perilaku seksual berisiko baik terhadap terapi biskill. Penelitian senada pada remaja di Kabupaten Sleman, diperoleh mayoritas responden memiliki sikap yang kurang baik berkaitan dengan bahaya Nrkoba dalam konteks kesehatan reproduksi dengan perilaku pencegahan HIV/AIDS yang baik. Jika dilihat dari latar belakang pendidikan responden mayoritas menyelesaikan di level SMP yakni sebanyak 69,1\% (Muslihatun, 2015). Penelitian ini tidak sejalan dengan teori yang menjelaskan pembentukan perilaku berasal dari pengetahuan dan sikap yang positif, sikap yang baik, dan pengetahuan selalu memegang peranan penting (Notoatmodjo, 2012).

Penelitian yang dilakukan Liddle, (2010) menujukkan intervensi brief therapy cukup efektif dalam peningkatan pengatahuan pada remaja di Australia tentang perilaku seks aman dan meningkatkan perilaku. Penelitian senada tetang konseling singkat berfokus solusi untuk meningkatkan orientasi masa depan bidang pendidikan pada remaja SMP 4 Pandak Bantul. Hasil penelitian ini menunjukkan ada perbedaan orientasi masa depan kelompok intervensi dan kontrol dan intervensi konseling singkat berfokus pada solusi memberikan pengaruh signifikan terhadap peningkatan orientasi masa depan remaja (Dewa Ayu E, 2014). Penelitian terkait dengan life skill dengan tema pengaruh life skill terhadap perilaku seks pada remaja di Wilayah Kota Palembang menunjukkan ada pengaruh dari aspek hards skill berupa pengetahuan dan soft skill yang berupa religiusitas, kepercayaan diri, dan konsep diri terhadap perilaku seks pada remaja (Martasari, 2019). Hasil penelitian senada dengan tajuk "Empowering adolescents with life skills education in schools" menujukkan remaja memiliki harga diri yang jauh lebih, persepsi koping yang memadai, penyesuaian tugas sekolah yang lebih baik secara umum, hubungan dengan guru dan perilaku prososial (Srikala \& Kishore Kumar, 2010).

Menurut teori Planned Behavior dimana sikap, pendidikan, kecerdasan, paparan informasi akan mempengaruhi perilaku seseorang. Sejalan dengan yang mejelasakan bahwa tingginya pengetahuan seseorang akan memotivasi individu untuk berperilaku sehat, akan 
tetapi kenyataannya dimana pengetahuan belum cukup dalam merubah perilaku seseorang (Emilia \& Prabandari, 2019).

Salah satu faktor yang dapat mempengaruhi sikap terhadap kesehatan yaitu lembaga pendidikan (Notoatmodjo, 2012). Melalui proses pembelajaran dapat menumbuhkna dan mengembangkan sikap. Hasil penelitian menujukkan bahwa tingkat pendidikan dan proses belajar anak jalanan di Kabupaten Kudus sangat rendah. Kesimpulan ini dapat menejelaskan kemungkinan remaja komunitas tersebut memiliki daya tangkap terhadap informasi yang cukup rendah. Sehingga proses internalisasi informasi yang disampaikan tidak dapat diterima dengan respon aplikasi sikap yang tentu berpengaruh pada pencegahan perilaku seksual berisiko trekait dengan kesehatan reproduksi.

Edukasi dalam bentuk pembelajaran melaui terapi biskill yang mengkobinasikan konseling dan pendidikan kecakapn hidup menjukkan efektifitas dalam meningkatkan pengatahuan dan sikap dalam mencegah perilaku seksual berisiko. Akan tetapi penyelengaraan pelayanan kesehatan dan intitusi pendidikan harus ramah. Berdasarkan pernyataan dari remaja di SMPN 27 Samarinda, kecenderungan malas untuk bercerita dengan guru karena alasan hukuman yang akan didapatkan.

Sumber daya yang ramah diperlukan dalam pelaksaan pelayanan kesehatan reproduksi pada remaja sebagai upaya dalam mencegeh perilaku berisiko. Tujuannya agar remaja tidak malu dan takut mengungkapkan permasalahan yang mereka hadapi. Upaya peningkatan pendidikan seks dengan kampanye agar tidak melakukan seks secara bebas serta diskusi interaktif dalam membicarakan permasalahan reproduksi secara leluasa, keterbukaan dengan orangtua, guru dan orang dewasa lainnya diharapkan dapat meningkatkan pemahaman tentang kesehatan reproduksi (Putriani, 2010).

Pengetahuan tentang AIDS dan IMS diperoleh dengan meningkatkan pemberian informasi. Permasalahan yang terjadi saat ini minimnya pendiidkan kesehatan, kurang komprehensif dalam menjelaskan informasi kesehatan, terbatasnya media informasi di sekolah dan rendahnya pemnafaatan PIKR sebagai layanan kesehatan reproduksi di sekolah (Ginting \& Tahlil, 2018). Hal yang menjadi diperhatikan guru dan tenaga kesehatan untuk menggalakan terus promosi kesehatan kesekolah dengan memberikan informasi yang tepat, dengan didukung pemnafaatan media yang menarik.

\section{SIMPULAN}

Hasil analisis uji statistik menunjukkan bahwa pada variabel pengetahuan dan sikap diukur dengan uji $\mathrm{t}$ dependent menujukkan nilai $p$ adalah 0.000. Hasil tersebut dapat disimpulkan bahwa adanya pengaruh yang bermakna skor pengetahuan sebelum dan sesudah diberikan intervensi biskill. Sehingga dapat disimpulkan hipotesis alternatif diterima dengan kesimpulan terdapat pengaruh biskill dengan peningkatan pengetahuan dan sikap remaja di SMPN 27 Samarinda.

\section{SARAN}

Diharapkan puskesmas dapat meningkatkan dalam memberikan pelayanan perkesmas melalui upaya promosi kesehatan di setting sekolah. Agregat remaja adalah kelompok resiko yang memiliki potensial terhadap masalah kesehatan sehingga menjadi perhatian penting dalam mengembangkan layanan PKPR di sekolah. Penelitian berkaitan dengan evaluasi 
program PKPR di sekolah, pematauan kegiatan kader remaja di sekolah dan ketelibatan guru dalam pembelajaran untuk meningkatkan soft skill remaja.

\section{REFERENCES}

Al Amin, M., Efendi, A., Hariyono, P., \& Yanuar, A. (2019). Efektifitas pembinaan kader kesehatan remaja (KKR) tentang trias uks terhadap upaya pencegahan kenakalan remaja pada siswa tingkat SMA/MA. PROFESSIONAL HEALTH JOURNAL, 1(1), 27-38.

Arnett, J. J. (2014). Emerging adulthood: The winding road from the late teens through the twenties. Oxford University Press.

Ayundari, D. S., \& Rahman, F. F. (2017). Hubungan Peran Kader Kesehatan Remaja dengan Tingkat Pengetahuan Kesehatan Reproduksi pada Siswa-Siswi SMP Al-Azhar Syifa Budi Samarinda. Jurnal Mahakam, 2.

Belsky, J., Rovine, M., \& Fish, M. (2014). The developing family system. Systems and Development, 22, 119-166.

Catio, M. (2009). Peran Pendidikan dalam Mengatasi Masalah Kesehatan Remaja. Aviable from: Http://Www. Idai. or. Id/Remaja/Artikel. Asp.

Desyolmita, N., \& Firman. (2013). Hubungan Persepsi Dengan Peranan Siswa Dalam Pelaksanaan Program Kegiatan Pusat Informasi Konseling Kesehatan Reproduksi Remaja Di Smp N 2 Pariaman. Konselor: Jurnal Ilmiah Konseling, 2(1), 213-219. https://doi.org/10.24036/02013211006-0-00

Dewa Ayu E. (2014). Meningkatkan Orientasi Masa Depan Bidang Pendidikan Pada Remaja SMP 4 Pandak Bantul. Yogyakarta. Jurnal Fakultas Psikologi, 1(0274), 23-34.

Emilia, O., \& Prabandari, Y. S. (2019). Promosi kesehatan dalam lingkup kesehatan reproduksi. UGM PRESS.

Esadia, N. K. (2019). Parenting: Counselling in the Home by Geoffrey Wango and Agnes. Parenting: Counselling in the Home.

Gavin, L. E., Catalano, R. F., David-Ferdon, C., Gloppen, K. M., \& Markham, C. M. (2010). A review of positive youth development programs that promote adolescent sexual and reproductive health. Journal of Adolescent Health, 46(3), S75-S91.

Ginting, E. D., \& Tahlil, T. (2018). Persepsi Mahasiswa Tentang Perilaku Seksual Pranikah. JIM FKep, IV(1), 50-55.

Hidayatun Najah, S. (2010). GAMBARAN PERILAKU SEKSUAL MAHASISWA INDEKOST/RUMAH KONTRAK DI NGAMPILAN KOTA YOGYAKARTA TAHUN 20101 Hidayatun Najah 2, Sulistyaningsih 3. Journal Health of Studies Vol 2, No. 1 Maret 2018, Pp. 24-29HeS (Journal of Health Studies).

Liddle, H. A. (2010). Multidimensional Family Therapy: A Science-Based Treatment System for Adolescent Drug Abuse. The Wiley-Blackwell Handbook of Family Psychology, January 2010, 341-354. https://doi.org/10.1002/9781444310238.ch23 
Martasari, T. (2019). Hubungan antara Konforitas Dengan Perilaku Seksual Pranikah pada Siswa SMA X Kota Pelembang. Jurnal Fakultas Psikologi Universitas Sriwijaya, 1, 4052.

Notoatmodjo, S. (2012). Promosi kesehatan dan perilaku kesehatan. Jakarta: Rineka Cipta, $45-62$.

Nurhayati. (2013). Hubungan pola Komunikasi dan Kekuatan Keluarga dengan Perilaku Seksual Berisiko pada Remaja di Desa Tridaya Sakti Kecamatan Tambun Selatan Kabupaten Bekasi. Jakarta, 1(2), 122-129.

Nursalam. (2016). Metodologi Penelitian Ilmu Keperawatan. Salimba Medika.

Purwanto, E., \& Kalsum, U. (2018). GAMBARAN PERILAKU SEKSUAL PRANIKAH REMAJA. Mahakam Nursing Journal, 2(3), 126-133.

Putriani, N. (2010). Faktor-faktor yang memepengaruhi pengetahuan remaja tentang kesehatan reproduksi di SMA Negeri 1 Mojogedang. Semarang: Universitas Diponegoro. http://eprints.undip.ac.id/10681/

Riset Kesehatan Dasar. (2013). Riset kesehatan dasar 2013. Jakarta: Badan Penelitian Dan Pengembangan Kesehatan RI.

Srikala, B., \& Kishore Kumar, K. V. (2010). Empowering adolescents with life skills education in schools-School mental health program: Does it work. Indian Journal of Psychiatry, 52(4), 344-349. https://doi.org/10.4103/0019-5545.74310

Suwarni, L., \& Selviana, S. (2015). Inisiasi Seks Pranikah Remaja Dan Faktor Yang $\begin{array}{llll}\text { Mempengaruhi. Jurnal Kesehatan } & \text { Masyarakat, }\end{array}$ https://doi.org/10.15294/kemas.v10i2.3378

Undang-Undang. (20 C.E.). tahun 2003 tentang sistem Pendidikan Nasional.

Wafi Nur Muslihatun, M. Y. S. (2015). Antisipasi Remaja terhadap Bahaya Penyalahgunaan Narkoba dalam Triad Kesehatan Reproduksi Remaja di Sleman. Jurnal Kebidanan Dan Keperawatan Aisyiyah, 11, 41-50. 